\title{
The State and State Power: Theoretical and Methodological Dimensions of Conceptual Evolution
}

\author{
Valentin Ya. Lyubashits ${ }^{1}$, Alexey Yu. Mamychev ${ }^{2}$, Sergey S. Shestopal ${ }^{3}$, Ludmila V. Perevalova ${ }^{4} \&$ Slinko T. \\ M. ${ }^{5}$ \\ ${ }^{1}$ Doctor of Law, Professor, South Federal University, Rostov-on-Don, Russia \\ ${ }^{2}$ Dr. habil. in political science, Phd in legal science, prof. Vladivostok State University of Economics And \\ Service Far Eastern Federal University, Russia \\ ${ }^{3} \mathrm{PhD}$ in Law, Associate Professor of Law Department, Vladivostok State University of Economics and Service, \\ Vladivostok, Russia \\ ${ }^{4}$ Head of the Department of Law, Professor of the Department of Law, Ph.D. in Philosophical Sciences, \\ Associate Professor, National Technical University «Kharkiv Polytechnic Institute» Kharkiv, Ukraine \\ ${ }^{5} \mathrm{PhD}$ in legal sciences, Associate Professor of the Departmentof Constitution law of Ukraine of Yaroslav \\ Mudryi National Law University, Kharkiv, Ukraine \\ Correspondence: Valentin Ya. Lyubashits, Doctor of Law, Professor, South Federal University, Rostov-on-Don, \\ Russia. E-mail: kafedra_tgp@mail.ru
}

Received: June 9, 2019

doi:10.5539/jpl.v12n5p103
Accepted: August 25, $2019 \quad$ Online Published: August 31, 2019

URL: https://doi.org/10.5539/jpl.v12n5p103

\begin{abstract}
The modern approaches to the evolution of the concepts of state and state power in a globalizing world is a subject of the paper. State power as the state evolves because of the need to address the systemic problems of society, requiring the development of new quality management resources. State power, like the political system, formulates and implements the collective goals of society or groups existing in it. The authors focus on the use of system-structural, functional methods of analysis of the state and state power, which makes it possible not only to explain state and political changes, but also to predict them. The authors substantiate the relevance of the methodological approaches of prominent economists and sociologists Schumpeter and Hayek to analyze contemporary problems of democracy, when the adaptive capacity of a state is aimed at reducing and reducing its role in the life of modern global society.
\end{abstract}

Keywords: State, Evolution of the State, Statehood, Political Society, State authority, Public power, Sovereignty, Democracy, Human rights, The rights of the nations, Constitutional rights.

\section{Introduction}

The problem of state and political power is one of the priorities in modern state-legal theory. This is due to the fact that the state is the main institution of political power in society, a central element of its political system, a means of establishing and maintaining public order, and coordinating the interests of various segments of the population.

The history of the evolution of the state and state power clearly showed the relevance of the choice of methodological tools to a particular political and legal ambiance, the structural context of the era. This or that type of state generates not only the corresponding type of state power but also the methodology of its analysis.

The variety of methods used in this area is extremely diverse. V.G. Ledyaev rightly notes that "modern kratology -"the science of power"- is an information retrieval system in which competing research programs are presented" [Ledyaev, 2011].

\section{Method of Study}

The range of data and the multiplicity of methods that can be applied in the study of state and state power have made the system-structural method the central one in political and legal research. The system-structural approach integrates system analysis and structural functionalism and essentially represents two aspects of a unified system approach to the analysis of the conditions of functioning and development of the state and state power. 
The concept of state power is operational for this work. State power is defined as a kind of political power, limited to the sphere of state institutions and government institutions. It also, like the political system (according to Almond), formulates and implements the collective goals of society or groups existing in it. Государственная власть (правительства, или государства) - это часть политической системы, обеспечивающая выработку политического курса. Она формируется под влиянием внутреннего и международного окружения и в свою очередь формирует его.

The system-structural method is becoming increasingly important in the field of public administration research since it allows us to develop a system of knowledge about the state and state power that can be verified; it allows evaluate political experience, the activities of state institutions, the political-state process as a whole from the point of view of causal relations, to foresee trends and consequences of government decisions. Thus, the system-structural method makes it possible not only to explain state and political changes, but also to predict them.

The principles of the system analysis of the state and state power include:

- the principle of social conditionality of the development of the state and state power, which consists in solving the adaptation problems of society that require new management resources;

- the structural and functional principle that focuses on the study of the differentiation of the structural components of the state and state power and their regulatory integration, allowing innovative state functions; formulating an acceptable approach to construction of a well-functioning system of political institutions of modern society in a globalized world, the formation of an optimal global order;

- an institutional approach focusing on the study of the principles of organization and interaction of the central and regional authorities; the order of formation of state bodies and control over their activities.

\section{Principal Part}

State power, as well as the state, is evolving due to the need to solve systemic problems of society that require the development of qualitatively new managerial resources. In the evolutionary aspect the management resources are the differentiation of the structural components of the state and state power and their regulatory integration. A functionally organized state embodies a type of activity that satisfies the need of society for self-preservation and purposeful organization. The new evolutionary phase of the development of the political organization of society is not only a more effective way to fulfill the old functions, but also the emergence of new ones that reveal the possibilities for the development of other structural components of the state. In its utmost development in the conditions of the emergence of a qualitatively new system of functions, a change in the political-legal regime complex takes place.

In the societal community, as shown by T. Parsons [Parsons, 1993], there is a certain political and legal regime in which the coercion mechanism plays a significant role. An autonomous legal system is developing, which is an important indicator of the differentiation of the societal community itself. This is due to the need for authoritative interpretation of institutionalized regulatory prescriptions. The political - legal regime supports not only the normative order, but also exercises control over the behavior within the boundaries of a certain territory. Consequently, the management function includes responsibility for maintaining the territorial unity of the regulatory order in the state. This functional imperative has two aspects: internal and external. Domestic concerns the conditions for imposing general norms on the performance of necessary functions by various elements of society. The exterior one aims to prevent destructive interference from the outside. The use of physical force may be the ultimate means of preventing destructive action. The control of the organized exertion of physical force, provided by the unity of management institutions, is, according to Parsons, one of the basic functional needs of state power. Thus, the primary need of a state-formed society is the coordination of the activities of its citizens with regulatory requirements. In other words, the primary functional need of state power is to maintain a single regulatory order throughout the territory.

Among the most important structural components of the state and society - values, norms, collective organizations, roles - Parsons attached particular importance to the latter component. The adaptation plays the primary function in the social system. And the process of enhancing adaptive capabilities is the most important among the processes of evolutionary changes from the point of view of perspective. The differentiation is a primary indicator of adaptive capabilities - a process in which an element, subsystem or set of them is divided over time into several elements or systems that differ both in structure and in their functional role within the framework of a new system. Each newly separated subsystem should be more adapted for the implementation of its primary function compared with the previous form and the previous level of its implementation (function). 
Parsons calls this process as "adaptive enhancement." The differentiation processes directly affect the integration of the system. Integration is associated with the need to coordinate the actions of the new set of structural elements, and hence the functions. Adaptive enhancement requires that new particularized abilities do not repeat; do not reproduce the functions of previous structures.

\subsection{The Principle of Subsidiarity}

Analysis of the conditions of stability of the political system and the survival of society, carried out by Parsons, was continued by another representative of the structural analysis G. Almond. Almond, trying to resolve the problem of stability and permanence of structures, explores the functions that contribute to the maintenance of the system. These are the functions of regulation, extraction (resources) and distribution. The result is the state activity, which in turn generates new input signals, new requirements for state power. New signals either strengthen or reduce support for the political system and officials in power. [Gabriel, 2008].

The system level of analysis of the state and state power involves focusing on three parameters - order, predictability, and stability. Almond and Powell distinguish between two types of values: the integrity of the system and the adaptive properties of the system. These system "values" reflect the functioning and effectiveness of all public authorities. Their activities are aimed at maintaining the stability and predictability of the processes occurring in domestic and foreign policy, as well as the ability of structural adaptation to changing external conditions and to respond to emerging challenges.

Among the main tasks of the system-structural approach is the analysis of the contradiction between centralization and decentralization in public administration. Constructing vertical of power in Russia will have certain implications for the further development of federalism, as well as municipal governments.

It is characteristic that the reform of state administration in Western countries and in Russia is going in opposite directions. The trends observed in developed countries in the field of public administration indicate that the potential of efficiency is not aimed at increasing the role and importance of state power in the life of society (centralization), but at reducing and contracting its former functions. Since the $80 \mathrm{~s}$ there is a decrease in the role of the (European) state by transferring its functions, on the one hand, to the EU level, and on the other to a lower, municipal level. Decentralization and crowding out of the state gives rise to new methods of government, new conditions are created for the organization of the society itself and its management. Jessop notes: "The management works in favor of the concept of "hierarchy"- that is, horizontal self-organization among interdependent actors" [Jessop, 2000]. What is happening in the governance system of the West is called a large-scale revolution in the relations between the state, public administration and society [Smirnov,2000]. Recoded processes demonstrating qualitative changes in the self-organization of a certain part of the human community should not be ignored by the theoretical attention of Russian social scientists, especially lawyers.

A comprehensive analysis of these problems is actualized by the fact that political, social and economic consolidation of power is still incomplete for Russia, despite a number of positive changes that have occurred in recent years - a weakening tendency towards regionalization, important structural reforms, etc.

What do we see in the Russian political process over the past few years? The presence of the district level of power creates an already four-level structure, including the federal, district, regional (subject of the federation) and municipal levels. At the same time, political resources did not move to the underlying components of the power pyramid, namely, to the regional one, and especially to the level of local self-government. According to subsidiary expert Kathleen Theple, the principle of subsidiarity includes the rule that a direct partner can be higher or lower by only one level. This protects the lower level from undue interference with its decisions [Tepl,2007].

If within the framework of the European Union, the efforts of direct cooperation of the European Commission with regional and local authorities are made, in Russia local self-government remains as a stepdaughter. This law "On general principles of the organization of local self-government in the Russian Federation" confirms this statement.

The Law clearly states that local self-government bodies are created, first of all, in connection with the delegation of part of the powers by the population to solve issues of local significance, while simultaneously vesting the relevant sufficient competence. But there is no clarity in terms of establishing the right of local governments to delegate their individual powers to state authorities of the constituent entity of the Russian Federation. The principle of subsidiarity, which means that functions that cannot be carried out quite effectively at the lower level, falls under the jurisdiction of the upper level. Here the motion vector is important - "from the bottom up", in which individuals, specific citizens are the main units of government in the state. 
It is clear that the Constitution of the Russian Federation (Articles 12, 130, 132) proclaims the independence of local governments, establishes their apartness from the system of government bodies; at that the possibility of the transference of certain municipal powers to state bodies is not provided for by the Constitution.

Without fixing the principle of subsidiarity, the state paternalism, manifested in the "top-down" movement will be legally imposed on Russian people.

Of course, the policy of "strengthening the vertical of power" will affect the retardation in the development of local self-government. However, with the solution of the vital issue - the consolidation of power throughout the territory -problems associated with increasing of the efficiency of the local level of power inevitably there will appear again and again. This thesis is repeatedly pointed out by the president of Russia: ".. without effective local self-government, I consider it is impossible to effectively organize power in general" [Putin, 2002].

At the same time, it is necessary to give a record of the fact that the process of decentralization, for example, in the conditions of the Caucasian region, and to a large extent the entire Russian space, did not have a positive impact on society due to the lack of stable traditions of self-government and self-organization or lack of it institutions of civil society and the traditions and power of law. It is the presence of developed institutions of civil society that traditionally allows the state and state power to act as a consolidated structure expressing the generalized interest of the society, including its weakest segments.

The key concept of a category of the system implies the presence of an object interacting with the environment or surroundings. Therefore, the state and state power as a system object exists both in the internal and external, international environment. The system receives input signals from these surroundings and attempts to influence the external environment with output signals.

\subsection{Corporative Structures of Modern Russia, Comparative Retrospective}

One of the important aspects of relations between the state, the government, and society, revealing the nature and dynamics of a specific attitude, is the institutional aspect. Institutional infrastructure includes diverse operating forces, each of which represents itself in its own way. A number of political scientists distinguish, on the one hand, the organizations of political representation - state bodies, political parties, etc., and on the other hand, various groups of interest included in the system of functional representation. The corporation is the most significant structural element of the functional representation.

The subject of this section of the paper is the particularities of democratic processes in the corporative structures of modern Russia in a comparative retrospective.

Before identifying the special characteristics of corporate democracy in Russia, as a system of functional representation, it is necessary at least in general terms to consider the basic concepts of democracy and to identify the conceptual belonging to them (concepts) of the corporate form of democracy. We will come to the conclusion that the "corporate" structures, as an integral part of the functional representation system, are the intermediate establishment and they can be turned in both directions - both to the "democracy of the owners" and the administrative "managed democracy".

It turns out that Russia is much more prone to a state, paternalistic model of economic democracy, including its corporate component.

S.N. Eisenstadt in [Eisenstadt, 2002] consideres democratic regimes as the natural political institutionalization of Modernity with its increased need for variability and adaptability. The constitutional and participatory concepts of democracy are also analyzed there.

Both of these concepts were rooted in the historical, ideological and institutional foundations of the cultural and political program of modernity.

Constitutional interpretation and the concept of democracy were formulated by J. Schumpeter in [Schumpeter, 2003]. In contrast to the "classical doctrine" of democracy, which proceeded from the idea of the "common good" and the political system intended for its implementation, Schumpeter defines democracy and its method as such an institutional tool for political decision-making, in which individuals acquire the power to make decrees by competing for votes [Schumpeter, 2003].

In politics, as in the economy, there are laws of competition, that is, people who claim to be leaders and who want to gain political power enter into the competition for votes. The element of competition is the essence of democracy and the theory of competitive leadership, according to Schumpeter, provides a satisfactory explanation for the facts of the democratic process.

The classical theory of democracy (more precisely the democratic method) in the heyday of capitalist society 
dominated the process of political and institutional changes. Democracy was a practical tool for reconstructing the forms of social and political structure that preceded the rule of the bourgeoisie. Moreover, the ideology of democracy was based on a rational interpretation of human actions and life values. Schumpeter defined the classical doctrine of democracy in the following way: "a democratic method is such an aggregate of institutional political decision-making tools, with the help of which a common good is accomplished by providing the people themselves with the opportunity to solve problems through elections of individuals who gather to fulfill their will" [Schumpeter, 2003]. We will not dwell on the criticism of this model of democracy by Schumpeter, we note that he devoted a whole paragraph to identifying the causes of the survival of the classical doctrine. His arguments on this topic continue to retain their relevance for today's Russia, which has embarked on the path of modernization. For example, we give four positions.

First, this is a doctrine of collective action. For many of those who remained with their religious (socialist) convictions, the classical doctrine became their political supplement. The authors specifically turn attention to the analogy of religious and socialist convictions;

Secondly, the forms and phrases of classical democracy for many nations (Russia is not an exception) are associated with the events of their history, perceived by the overwhelming majority of the population with certain enthusiasm;

Thirdly, there are social structures where the classical theory of democracy is in concord with the facts. This primarily applies to industrially underdeveloped societies;

Fourthly, politicians use such phraseology that flatters the masses and makes it possible not only to avoid responsibility, but also on behalf of the people to crack down on their opponents.

\subsection{On Democracy Once Again}

Schumpeter also finds explanations for the frankly egalitarian nature of the classical theory of democracy.

Let us note one significant point in the discourse of a scientist who is important for our further analysis of various forms of democracy and the choice of the Russian way of democratic transformations. Schumpeter emphasizes that "one cannot expect effective functioning of democracy until the overwhelming majority of people in all classes agree to obey the rules of a democratic game, which in turn means that they mostly agree with the fundamental principles of the institutional structure" [Schumpeter, 2003]. Failure to comply with the latter condition forced the scientist to propose and substantiate another theory of democracy. The theory of competitive leadership implies that competition depends on strict adherence to constitutional rules and regulations.

Eisenstadt designates another interpretation of democracy as participatory. This is a form of democracy in which government is exercised not by oligarchic groups, but by a "mass" that includes all citizens. The researcher in this interpretation identifies two main types: "republican" and "communitarian". The first focuses on the importance of responsible citizen participation in the political process, no matter what limitations are encountered along the way. The latter view participation as a public good that can manifest itself not only in the national political arena, but also in no less important spheres of life: at the local level, the workplace, etc.

Eisenstadt identifies the institutional and ideological implications of a particular interpretation of democracy: "The most important thing is that constitutional and participatory interpretations of democracy differed in terms of which of the two fundamental values accompanying the establishment of democracy - freedom or equality — they put at the center." [Bytyak, et al 2017].

If the constitutional interpretation of democracy with all its modifications was associated primarily with the legacy of representative institutions and practices, then participatory versions focus on the importance of participation at any level of public life, including intermediary institutions or associations.

We are more interested in the position of communitarian versions of participatory democracy since they are the ones who correspond to the task of researching the corporate form of democracy. Representative authorities are regarded by communitarians as important vehicles and instruments for overcoming deep inequality that hinders the successful functioning of a democracy. The rather cautious perception of representative institutions is associated with the fear that they do not always contribute to the full participation of citizens in political life and may preserve the inequitable distribution of power and wealth at any level of social life: at the level of the social community as a whole, the local community or the labor collective.

Thus, the position of participatory democracy is not alien to turning towards economic democracy. Economic democracy is undoubtedly linked to the democratic quality of society. T. Masaryk asserted that true democracy 
includes not only political but also economic and social democracy. S. Ringen notes in [Ringen, 2004]: "If we have democracy in political life, but it does not exist in economic life, and if the weight of economic power grows in proportion to political power, citizens have the right to ask themselves the question: how democratic is their society "in fact" and "is it really" political democracy for something good ".

Interestingly, the same J. Schumpeter quite critically and with a certain degree of theoretical doubt in the pages of his book (Capitalism, socialism, and democracy) spoke about industrial or economic democracy. For him, this collocation "appears in so many quasi-utopias, that it has very little exact meaning" [9, p. 391]. The meaning of this term is revealed in a footnote, which also confirms its "status" in the eyes of a scientist. He is confident that much of this economic democracy will dissolve without a trace under the socialist regime, since many of the interests that this type of democracy should protect will, according to Schumpeter, simply cease to exist. After all, the main problem (the "favorite method" according to Schumpeter) is the division of profits between the entrepreneur and the worker. Speaking about the fate of the democratic method in the conditions of socialism, the author clearly realized that socialism cannot offer an obvious solution to the problem since there will be no political class with stable traditions. The fate of democracy is in his hands, but the destruction of the institutional structure of a capitalist society, the basis of which is "property" and "freedom of contracts", is the main threat to democracy. According to the researcher, the shareholder form of business organization contributed to the destruction of the institutional structure of capitalist society, and, consequently, of its democratic method, for all that this form was a product of the capitalist process.Based on their commitment to the fundamental values of private property and free contractual relations, the monopolization of the corporation undermines the viability of the capitalist system.

This kind of reasoning probably fit into neoclassical economic theory, which until 1950 ignored a firm (corporation) as the most common form of organization under capitalism and focused on explaining how price theory explains the market structure [Stigler G.].

"The capitalist process," Schumpeter firmly notes, "replacing the walls and equipment of the plant with a simple bundle of shares, delude the very idea of ownership. It weakens the grip of the owner, who was once so strong, the legal right and the actual ability to dispose of his property at his own discretion "[ Stigler G]. A monopolized corporate business testifies to the disintegration of capitalism, on the one hand, and, on the other, the establishment of the institutional structure of another social system - socialism. Thus, the subject of research of the scientist is to identify the tendency of development of society from one social order to another. From capitalism to socialism. This transition is accompanied by conflicts and clashes of economic interests that are still of a political nature.

It is characteristic that another researcher of similar socio-political processes, practically in the same historical period F. von Hayek, gave similar conceptual assessments of what is happening. This period in the development of social structures was called by Hayek a "corporate", "syndicalist" society. In a corporate society, organized industries will be something of a relatively independent state in the state. Subsidies for many groups are beginning to be determined not by market relations, the results of economic processes, but by the course of the political process, by the power of political representatives of various industries. F. Hayek foresaw a similar development of events, only analyzing the gradual slipping of the Western democracies through the growth of state regulation to totalitarianism. He noted that "it is not the assessment of the merits of individuals or groups by the majority (consumers in the market), but the power of these individuals or groups aimed at getting special advantages out of the government - this is what determines the distribution of income" [Hayek, 1994]. Distributive conflicts endlessly tear apart the social and political canvas of society, making it extremely unstable and disordered [Shestopal, et al 2017; et al 2013].

How can individual, group and national (state) interests coincide in such a society? Hayek writes: "A state engaged in the comprehensive planning of monopolized industries will have a crushing power in relation to an individual ... The gears of monopolies will become powerful mechanisms of the state itself, which will increasingly serve the interests of the apparatus, but not the interests of society as a whole" [Hayek, 1994].

\subsection{Actuality for Modern Russia and Conclusion}

The crisis of the radical (monetarist) method of transition to the market in Russia, which is based on institutional transformations, demanded an alternative approach - the structuralistic one, that is, the implementation of structural adjustment through active state participation [Baranov, et al 2017].

In this case, following the internal logic, the government should resort to controlling prices and incomes, establish tax breaks and fund social assistance programs to maintain or improve the welfare of certain groups in order to achieve a favorable distribution structure. Immediately the other groups who want to get similar benefits 
begin to put pressure on the state..

The corporate society, where the economy of organized groups play the main role, is the closest analogue of today's bureaucratic, "clerical" economy.

There are certain grounds for using the methodological approaches of Schumpeter and Hayek to analyze the problems of democracy not in the context of the transition from capitalism to socialism, but on the contrary, the transition from socialism to capitalism.

We can observe a point of coincidence (point of return?) of two tendencies of opposite nature. One leading to the socialist "future" of Western democracy, as it was seen in the 40s of the last century, and the other - to the capitalist "past" as it is presented today at the turn of the ages.

Then we can offer the thesis that "corporate" structures are intermediate formations and they can be turned in both directions - both to the market and to the administrative state [Lyubashits, et al 2017]. Such a system is a kind of criterion for the reversibility / irreversibility of social transformations. It is possible that the corporate base is the intermediate step that society, breaking with totalitarianism, is forced to do moving in the reverse order.

The democratization or diffusion of property that occurred in developed countries in the second half of the XX-th century shows the main vector of development of economic democracy in Russia, especially in its corporate sector.

\section{References}

Akbari, A., Abbasian, M., \& Jansooz, P. (2013). Application of RAP Model in measuring the capabilities of attracting sources in the economy: A case study of the tourism sector in Sistan and Balucestan. UCT Journal of Social Sciences and Humanities Research, 1(1), 16-21.

Almond, G. A. et al. (2008). Comparative Politics Today: A World View (9th ed.). University of California, San Diego, Pearson, Longman.

Baranov, P., Lyubashits, V., Mamychev, A., Kuchina, Y., \& Shestopal, S. (2017). Dynamics of governmental organization of the society: Evolutionary state-legal forms andmodern development trends. Man in India, 97(23), 543-550.

Bytyak, Y., Yakovyuk, I., Tragniuk, O., Komarova, T., \& Shestopal, S. (2017). The state sovereignty and sovereign rights: The correlation problem. Man in India, 97(23), 577-588.

Eisenstadt, Sh. N. (2002). The Paradox of Democratic Regimes: Fragility and Transformability. Polis, 2(3).

Hayek, F. A. (1994). The Road to Serfdom. University of Chicago Press.

Jessop, B. (2000). Governance failure. The New Politics of British Local Governance. L., p.15.

Ledyaev, V. G. (2001). Power: conceptual analysis. Moscow, Rosspen.

Lyubashits, V., Mamychev, A., Zueva, Y., Nadtochiy, J., \& Shestopal, S. (2017). Formation and Evolution of Separation of Powers : Global and Sociocultural State-Legal Practice. Man in India, 97 (23), 239-253

Putin, V. V. (2002). Russia needs to be strong and competitive. Russian newspaper. April $19^{\text {th }}$.

Ringen, S. (2004). Distributive theory of economic democracy. Logos, (2), 114. https://doi.org/10.1080/13510340412331294192

Schumpeter, J. (2003). Capitalism, socialism \& democracy. Taylor \& Francis e-Library.

Shestopal, S., Oleynikov, S., \& Yakovyuk, I. (2017). Models of the relationship between church, state and political society: Neo-Thomists' arguments. Man in India, 97(23), 499-508.

Smirnov, V. V. (2000). Some results of the Congress of IAP in Quebec. Polis, (6).

Stigler, G. (n.d.). The Organization of Industry. Homewood. Il,: Irwin Press.

Tanzi, V. (2007). The future of fiscal federalism, paper presented to the conference on 'New perspectives on fiscal federalism: intergovernmental relation, competition and accountability'. Berlin.

Tepl, K. (2003). Organizational structure of the European Union regional policy. 


\section{Copyrights}

Copyright for this article is retained by the author(s), with first publication rights granted to the journal.

This is an open-access article distributed under the terms and conditions of the Creative Commons Attribution license (http://creativecommons.org/licenses/by/4.0/). 